\title{
JADWIGA KIWERSKA
}

Poznań

\section{USA-Unia Europejska. Stan i perspektywy relacji transatlantyckich}

Jednym z ważniejszych procesów zachodzących obecnie na arenie międzynarodowej są przekształcenia w relacjach między Stanami Zjednoczonymi a Europą (Unią Europejską). Jest to między innymi efekt zmiany uwarunkowań funkcjonowania układu transatlantyckiego - tego wyjątkowego, zbudowanego po II wojnie światowej sojuszu Ameryki i Europy Zachodniej. W okresie zimnej wojny wspólnota transatlantycka miała jasno sprecyzowany cel lub inaczej - wyraziście zarysowanego przeciwnika. Rodziło to naturalną potrzebę wzajemnego i bliskiego współdziałania Ameryki i zachodniej części kontynentu europejskiego, zarówno w sferze bezpieczeństwa, jak i na polu politycznym i gospodarczym. Stany Zjednoczone ze swoim bezprecedensowym potencjałem, w tym przekraczającą możliwości Zachodniej Europy siłą militarną były gwarantem jej bezpieczeństwa wobec mniej lub bardziej realnego zagrożenia ze strony Związku Radzieckiego. Z kolei dla Ameryki sojusz z Europą Zachodnią w ramach NATO stanowił ważny czynnik jej rangi i pozycji w dwubiegunowym świecie.

Zniknięcie zagrożenia radzieckiego (świata komunistycznego) osłabiło fundamenty, na których w okresie zimnej wojny budowano stosunki transatlantyckie. Stwierdzenie to jest tak bardzo prawdziwe, że wydaje się już banałem. Jednak nie ma wątpliwości, że gdy zabrakło wspólnego wroga, to górę zaczęły brać partykularne interesy, do głosu doszły skrywane ambicje, ale też nowe oczekiwania i wyzwania. Napięcia w relacjach między Stanami Zjednoczonymi a ich sojusznikami europejskimi na początku lat dziewięćdziesiątych wynikały między innymi z rosnących aspiracji państw integrującej się Europy, w tym przede wszystkim Francji coraz śmielej popieranej przez zjednoczone Niemcy, w zakresie bezpieczeństwa i obrony. Wywoływały one bardziej lub mniej uzasadnioną irytację po drugiej stronie Atlantyku, aż do stawiania pytania - i to nie tylko przez kręgi izolacjonistyczne w Waszyngtonie, ale także przez administrację George'a H. W. Busha seniora - czy nie czas wycofać się z Europy, która okazuje się niewdzięcznym sojusznikiem i zapomina, że przez ponad czterdzieści lat bezpiecznie rozwijała się pod parasolem ochronnym Ameryki ${ }^{1}$.

Równocześnie zza Atlantyku docierały sygnały sugerujące, że Stany Zjednoczone nie zamierzają odgrywać w pojedynkę roli ,światowego żandarma”. Trudno było nie dostrzec wagi argumentów wysuwanych przez izolacjonistów amerykańskich, którzy po zakończeniu zimnej wojny z nową siłą domagali się wycofania Stanów Zjednoczonych z Europy. Twierdzono, że kontynent europejski nie znajduje się już na pierwszej

1 M. Brenner, P. Williams, The United States and European Security in the 1990s, w: Strategy in the New Europe, ed. C. McInnes, London 1992, s. 57. 
linii amerykańskiej obrony przeciwko radzieckiemu/rosyjskiemu zagrożeniu, a staje się głównym konkurentem gospodarczym Ameryki. Dlatego Waszyngton powinien zrezygnować lub ograniczyć swe zaangażowanie w Starym Świecie, nadszedł bowiem czas dokonania podziału sił, ciężarów i odpowiedzialności².

Z kolei europejskich partnerów Ameryki irytowała jej skłonność do arogancji i narzucania swej woli. Pogłębiająca się przepaść technologiczna między Stanami Zjednoczonymi a europejskim filarem NATO, a także samą Unią Europejską w zakresie możliwości militarnych dodatkowo zwiększała frustrację w stolicach europejskich. Doświadczenie bałkańskie, a zwłaszcza wojna NATO w obronie Kosowa pokazały, że Europa nie byłaby w stanie przeprowadzić samodzielnie - bez wykorzystania amerykańskich zasobów, logistycznych i strategicznych zdolności Ameryki - akcji wojskowych (a także dyplomatycznych) na swym własnym, europejskim podwórku. Wyrazem tej przewagi amerykańskiej myśli technicznej, możliwości finansowych, wreszcie zdolności amerykańskich firm zbrojeniowych był projekt systemu obrony antyrakietowej, podjęty jeszcze przez administrację Williama J. Clintona. Stał się on w Europie obiektem ostrej krytyki, gdyż uznano go nie tylko za początek nowego wyścigu zbrojeń i zarzewie kolejnych napięć w relacjach z Rosją, ale także kolejny dowód wyraźnej asymetrii potencjałów Ameryki i Europy (Unii Europejskiej). Koszt całego przedsięwzięcia szacowano bowiem na 80-100 mld dolarów, co było sumą gigantyczną w realiach europejskich.

Innymi słowy, Europa przejawiała coraz większe aspiracje i ambicje, ale równocześnie miała świadomość swej słabości i uzależnienia od Stanów Zjednoczonych, zwłaszcza pod względem militarnym. Nie mobilizowało jej to jednak do zwiększania nakładów na obronność, i to pomimo ciągłych apeli płynących z Waszyngtonu (budżety obronne sojuszników europejskich spadły od 1992 r. realnie o 22\%). Europa nie pozostawała jednak bierna, jeśli idzie o jej własne zdolności obronne. Rozwijana z różnymi efektami i przechodząca różne etapy europejska tożsamość obronna aż do powstania Europejskiej Polityki Bezpieczeństwa i Obrony (European Security and Defense Policy-ESDP) z jednej strony dowodziła woli wzmocnienia europejskiego filara we wspólnocie transatlantyckiej, z drugiej zaś - mogła stać się czynnikiem komplikującym relacje Unii Europejskiej z amerykańskim sojusznikiem, mimo wszystko dbającym o utrzymanie swej dominującej roli w relacjach z Europa.

A zatem układ transatlantycki wszedł w XXI wiek z wieloma niewiadomymi co do swej przyszłości. Wprawdzie zgadzano się, że pozostaje on na arenie międzynarodowej wartością trudną do przecenienia. „Świadomość własnego interesu i posiadanych stałych punktów powinna stanowić podstawę trwałego sojuszu Ameryki i Europy" - pisał Zbigniew Brzeziński ${ }^{3}$. Podkreślano, że Ameryka, jeśli chce realizować swe cele globalne, to musi posiadać strategicznych partnerów. Takim naturalnym sojusznikiem dla USA jest Europa, z którą łączy Amerykę ponad 50 lat bliskiego współdziałania oraz wypracowane przez ten czas standardy i instytucje. Europa zaś w przewidywalnej przyszłości, by czuć się naprawdę bezpiecznie, będzie nadal potrzebowała Stanów

2 T. G. Carpenter, Beyond NATO. Staying out of Europe's Wars, Cato Institute 1994, s. 36.

3 Artykuł Z. Brzezińskiego opublikowany w „National Interest”, przedrukowany pt. Jak żyć $z$ nowa Europq w „Gazecie Wyborczej” 24-25 VI 2000. 
Zjednoczonych. Jednak już wówczas analitycy i eksperci wskazywali, że konieczne jest wypracowanie nowej formuły partnerstwa atlantyckiego, w której Europa przyjmowałaby na siebie większe obciążenia, zarówno wojskowe, jak i finansowe, a Ameryka przystałaby na bardziej zrównoważony dialog i większą kolegialność w podejmowaniu decyzji. Przestrzegano, że mogą pojawić się nowe pola konfliktów, związanych choćby z narastającą konkurencją gospodarczą między czyniąca postępy integracyjne Unią Europejską a dominującą dotychczas w sferze ekonomii Ameryką. Powinno się zatem wypracować metody i środki, które - w sytuacji pojawienia się konfliktu interesów - ustrzegą wspólnotę transatlantycką przed rujnującymi ją napięciami i zawirowaniami.

Były to zadania, które na początku XXI wieku stanęły zarówno przed nowym amerykańskim prezydentem George'em W. Bushem juniorem, jak i przywódcami państw europejskich. Po obu stronach Atlantyku niewątpliwie istniała świadomość, że sytuacja wymaga działania, podjęcia prób umocnienia więzi transatlantyckich. Wobec wyzwań globalnych, takich jak niepewność co do kierunku przemian w Rosji, zagrożenia proliferacją broni masowego rażenia, nie do końca jeszcze zidentyfikowanej, ale już wyraźnie dostrzeganej groźby terroryzmu międzynarodowego nie można było dopuścić do osłabienia wspólnoty transatlantyckiej. Tymczasem splot okoliczności, a przede wszystkim bezprecedensowe wydarzenia spowodowały, że początek obecnego stulecia okazał się niezwykle dramatyczny dla układu transatlantyckiego. Doszło do zawirowań i kryzysów, które groziły jego rozpadem.

Otóż, przyjęta po ataku na Amerykę 11 września 2001 r. strategia walki z terroryzmem, przyniosła zgubne skutki nie tylko dla rangi i pozycji Stanów Zjednoczonych w świecie, ale także dla wspólnoty transatlantyckiej. Trudno wprawdzie odmówić racji administracji Busha, która działając w atmosferze ogólnonarodowej traumy wywołanej uderzeniem al Kaidy na Nowy Jork i Waszyngton, zdecydowała się podjąć stanowczą i skuteczną walkę z zagrożeniem terrorystycznym. Zresztą wówczas Stany Zjednoczone miały poparcie nie tylko swoich sojuszników europejskich, ale przeważającej części państw i światowej opinii publicznej. Efektem tego niemalże powszechnego odruchu solidarności z Amerykanami było - obok wsparcia ONZ - bezprecedensowe wprowadzenie w życie przez partnerów z NATO fundamentalnego art. 5 traktatu waszyngtońskiego mówiącego o wzajemnej obronie (,,jeden za wszystkich, wszyscy za jednego"). Następnie cała Europa przyłączyła się do tworzonej ad hoc koalicji antyterrorystycznej. Administracja Busha stanęła więc przed ogromną szansą wykorzystania dramatycznej sytuacji do stworzenia czegoś dobrego, jeśli nie nowego modelu stosunków w świecie, to przynajmniej umocnienia więzi transatlantyckich.

Szybko jednak okazało się, że prezydent Bush tej szansy nie wykorzystał. Co więcej, działania amerykańskie spowodowały, że Stany Zjednoczone zmarnowały wielki kapitał sympatii i olbrzymie możliwości oddziaływania na sytuację międzynarodową. Siła moralna, która tradycyjnie określała rangę Ameryki w świecie, a po 11 września miała bezprecedensowy wymiar, uległa ogromnej deprecjacji, zastąiły ją dość powszechne uczucia niechęci i wrogości wobec USA. Ze szczególną siłą te emocje ogarnęły większość państw europejskich, w tym tak lojalnego dotychczas sojusznika Ameryki jak Niemcy. Nie mogło to pozostać bez wpływu na stan relacji transatlantyckich.

Powodem tej ostrej krytyki, kierowanej pod adresem Stanów Zjednoczonych, była realizowana przez Biały Dom strategia walki z terroryzmem, której symbolem stała się 
„doktryna Busha”4. U jej podłoża legło przekonanie amerykańskich strategów, że zaatakowana Ameryka nie powinna podlegać żadnym ograniczeniom, a przeciwnie mieć daleko idącą swobodę działania, jeśli chodzi o użycie siły, zakres i charakter jej stosowania. Zdecydowano się więc wypowiedzieć wojnę nie tylko siłom terrorystycznym, ale również wspierającym je ośrodkom i państwom, które stwarzają bądź mogą stworzyć zagrożenie dla USA. Następnie pojawiła się formuła uderzenia powstrzymującego zagrożenie, czyli akcja prewencyjna. Uznano, że w epoce rozprzestrzeniania się broni o ogromnej mocy rażenia i w świecie „sprywatyzowanego" terroryzmu, gdy obowiązująca od półwiecza polityka odstraszania nie chroni już przed atakami, konieczne są działania wyprzedzające, zapobiegające groźbie ataku zbrojnego, użycia broni masowego rażenia, zamachom terrorystycznym. Kolejnym elementem „doktryny Busha” była możliwość odejścia od taktyki multilateralizmu. Stwierdzono, że w obliczu nowych dramatycznych wyzwań i zagrożeń Stany Zjednoczone zastrzegają sobie prawo do akcji samodzielnych - unilateralnych, nawet bez akceptacji wspólnoty międzynarodowej, utożsamianej z ONZ ${ }^{5}$.

Wprawdzie uderzenie na Afganistan w październiku 2001 r. odbywało się pod sztandarem koalicji i z mandatem ONZ oraz deklarowaną gotowością udziału całego NATO, to jednak w praktyce interwencja ta okazała się akcją stricte amerykańską. USA prowadziły ją niemalże samodzielnie (tylko Brytyjczycy wnieśli wkład wojskowy, a na lądzie działały siły afgańskie), wchodząc jedynie w dwustronne układy z niektórymi członkami NATO i nie konsultując z nimi większości decyzji. Różne były tego przyczyny. Pewną rolę odegrało poczucie własnej potęgi militarnej, ale też obawy Waszyngtonu o kunktatorstwo przywódców europejskich, będących pod rosnącą presją antyamerykańskich nastrojów społecznych ${ }^{6}$. Ale w rezultacie kampania afgańska, zamiast umocnić współpracę Ameryki z sojusznikami i potwierdzić znaczenie układu transatlantyckiego spowodowała głęboką rysę w relacjach Ameryki z wieloma partnerami europejskimi. Państwa te uznały, że USA je zignorowały, demonstrując arogancje i niechęć do dzielenia się odpowiedzialnością.

Sytuację potęgowała ostra ocena „doktryny Busha”, formułowana w głównych stolicach europejskich. Uważano, że stanowi ona swoistą rewolucję w polityce zagranicznej, gdyż łamie dotychczasowe zasady ładu międzynarodowego i jest wyraźną manifestacją amerykańskiej siły, arogancji i - jak przekonywali najwięksi krytycy - dążenia do hegemonii. Ostra polemika, towarzysząca nowej strategii amerykańskiej, ujawniła nie tylko rozbieżność poglądów co do charakteru i metod walki z nowymi zagrożeniami, ale była okazją do zamanifestowania narastającej w Europie niechęci do Ameryki, ukrytych kompleksów i zadawnionych konfliktów. Spór ten odzwierciedlał dwa sposoby myślenia o sytuacji międzynarodowej i roli Stanów Zjednoczonych w świecie. Oponenci, w tym większość sojuszników europejskich, wątpili, czy siła może eliminować

4 Założenia „doktryny Busha” znalazły się w: G. W. Bush, The State of the Union Address: January 29, The White House, Washington, January 2002; The National Security Strategy of the United States, The White House, Washington, September 2002.

5 I. H. Daalder, J. M. Lindsay, The Bush Revolution: The Remaking of American's Foreign Poli$c y$, The Brookings Institution, May 2003, s. 34 i n.

${ }^{6}$ Więcej na ten temat zob. J. Kiwerska, USA - osamotnione mocarstwo $w$ świecie zagrożeń, „Przegląd Zachodni” 2005, nr 1, s. 29. 
zagrożenia, odrzucali wojnę prewencyjną, uznając ją za działanie agresywne i sprzeczne z prawem. Przywiązani byli do dyplomacji jako najlepszej metody osiagania celów politycznych i likwidowania zagrożeń, zaś wizja Busha przywodziła im na myśl działania „szeryfa z Teksasu”, który siłą zaprowadza porządek w miasteczku, nawet wbrew woli jego mieszkańców ${ }^{7}$.

A zatem Amerykę i część jej najbliższych dotąd europejskich sojuszników różnił sposób myślenia o sytuacji międzynarodowej, skali zagrożeń i wyzwań, metodach przeciwdziałania niebezpieczeństwom. Robert Kagan, amerykański ekspert w dziedzinie polityki zagranicznej ujął to w zgrabną formułę, że Ameryka jest z Marsa, a Europa z Wenus ${ }^{8}$. Pojawiła się zatem sytuacja, wcześniej we wspólnocie transatlantyckiej nieznana, gdy to między jej państwami członkowskimi nie było zgodności co do spraw zasadniczych, stanowiących podstawę funkcjonowania, skuteczności i sensu jej istnienia.

Efektem było bezprecedensowe zachwianie układu transatlantyckiego. Odpowiadając na rewolucję Busha w polityce zagranicznej, nie zgadzając się z założeniami strategii amerykańskiej przywódcy niektórych państw europejskich przybrali niemalże konfrontacyjną wobec Waszyngtonu postawę. Dotyczyło to w pierwszym rzędzie Jacquesa Chiraca, prezydenta Francji, ale też Gerharda Schrödera, kanclerza Niemiec. Zwłaszcza postawa Berlina była wydarzeniem bez precedensu, wszak RFN uchodziła za niezwykle lojalnego i spolegliwego sojusznika Ameryki, której od zakończenia II wojny światowej zawdzięczała niemało. Tymczasem Niemcy wraz z Francją i Rosją stworzyły tzw. front odmowy, sprzeciwiający się planom Waszyngtonu i krytyczny wobec administracji Busha. Był to też wyraz buntu przeciwko amerykańskiemu prymatowi, potwierdzenie tezy, że zbyt silne mocarstwo rodzi nieuchronną próbę jego zrównoważenia i osłabienia, odreagowanie sytuacji, gdy Europa przez wiele lat była uzależniona od amerykańskiego patrona. Tym samym część Europy demonstrowała swe rosnące ambicje i wolę pewnego zdystansowania się od Stanów Zjednoczonych, a przynajmniej od polityki administracji Busha.

Praktycznym efektem tego „buntu” był kryzys decyzyjny w NATO, do którego doszło w lutym 2003 r., niemalże w przeddzień amerykańskiego ataku na Irak. Wtedy to Waszyngton nie mógł uzyskać zgody Sojuszu na dostarczenie Turcji systemu obrony przeciwrakietowej. Było to uderzenie w prestiż Ameryki, najsilniejszego członka Paktu Północnoatlantyckiego i to ze strony maleńkiej Belgii, która wspierana przez Francję blokowała zamiary Stanów Zjednoczonych. Świadomość, że przystępując do kolejnego etapu tak ważnej dla nich walki z terroryzmem USA nie mogą liczyć na wielu swych najbliższych europejskich sojuszników, musiała być dla Waszyngtonu niezwykle frustrująca i bolesna. Mogła poddać w wątpliwość - z amerykańskiej perspektywy - znaczenie i wartość NATO, głównego filara wspólnoty transatlantyckiej.

Atak na Irak w marcu 2003 r. z całą już siłą odsłonił kryzys we wspólnocie transatlantyckiej. Amerykanie wprawdzie mieli po swojej stronie część swych europejskich

7 Zob. szerzej: J. Kiwerska, Odwrót od rewolucji? Nowe elementy w amerykańskiej polityce zagranicznej, „Zeszyty Instytutu Zachodniego” 2006, nr 43, s. 12-14.

8 Wyrażone to zostało w jego głośnym eseju Of Paradise and Power. America and Europe in the New World Order, New York 2003, (wyd. polskie: Potęga i raj. Ameryka i Europa w nowym porzadku świata, Warszawa 2003). 
partnerów, w tym Wielką Brytanię, Włochy, Hiszpanię i niemal całą pokomunistyczną Europę, ale tak ważne państwa sojusznicze jak Niemcy i Francja wyrażały kategoryczny sprzeciw wobec wojny irackiej. Podobny był stosunek przeważającej części europejskiej opinii publicznej. W efekcie wojna iracka, a później jej dramatyczne konsekwencje, w tym terror rozprzestrzeniający się na wielką skalę w posaddamowskim Iraku oraz bulwersujące przykłady zachowań żołnierzy amerykańskich (Abu Ghraib) do tego stopnia wzmocniły antyamerykanizm w Europie, że popieranie Waszyngtonu stało się dla wielu jego dotychczasowych sprzymierzeńców niewygodne, wręcz groźne. Niektóre proamerykańskie rządy znalazły się pod rosnącą presją opinii publicznej, opozycji, populistycznych tendencji, krytycznych wobec polityki USA. Czy w tej sytuacji można było mówić o łagodzeniu różnic i napięć między Europą a Stanami Zjednoczonymi - z pewnością nie. Wprost przeciwnie - można było odnieść wrażenie, że Ameryka zyskała zdolność budowania koalicji nie wokół siebie - jak to było w przeszłości i na czym opierał się układ transatlantycki - ale przeciw sobie.

Niebezpieczna dla wspólnoty transatlantyckiej była również tendencja Waszyngtonu pogłębiania podziałów w Europie i polaryzowania stanowisk. Użycie przez sekretarza obrony Donalda Rumsfelda formuły o „starej” Europie - antyamerykańskiej i ,nowej” - proamerykańskiej to poczucie pęknięcia kontynentu spotęgowało. Groziło też dalszą dekompozycją nie tylko NATO, ale i Unii Europejskiej, która znajdowała się właśnie w przededniu poszerzenia o państwa z Europy Środkowo-Wschodniej, wyraźnie popierającej administrację Busha. Wśród przedstawicieli „starej” Europy, a zwłaszcza w Paryżu i Berlinie pojawiały się zatem głosy o wprowadzaniu amerykańskiego „konia trojańskiego” do Unii Europejskiej.

Wiele czynników spowodowało, że po obu stronach Atlantyku podjęto jednak wysiłki, aby nie dopuścić do dalszych spustoszeń w relacjach transatlantyckich. Sytuacja bowiem stawała się groźna zarówno dla Stanów Zjednoczonych, jak i dla ich adwersarzy w Europie. Przede wszystkim USA, uwikłane w trudny proces opanowywania chaosu i stabilizowania Iraku, ale również zmagające się z coraz trudniejszą sytuacją w Afganistanie, gdzie do aktywności zbrojnej powracali talibowie i terroryści islamscy, musiały uznać wagę współdziałania w szerokim froncie, szczególnie NATO-wskim. Administracja Busha na początku drugiej kadencji skonstatowała, że nawet największe mocarstwo świata nie jest w stanie samo podołać groźnym wyzwaniom współczesności. Niezależnie od tego, czy chodziło o zmiany klimatyczne, o rozprzestrzenianie broni masowego rażenia, terroryzm, czy ,upadające” państwa - były to wyzwania, którym trudno sprostać bez współdziałania z partnerami europejskimi. Także „stara” Europa wydawała się zmęczona ,przeciagganiem liny” z Waszyngtonem i deklarowała wolę naprawiania więzi transatlantyckich. Rozumiano, że bezpieczeństwo Europy w świecie trudnych wyzwań i nierozstrzygniętych nadal problemów zależy od dobrego i skutecznego funkcjonowania układu transatlantyckiego. Dostrzegano też zgubne skutki podziałów na kontynencie dla procesu integracji europejskiej i budowania silnej Europy ${ }^{9}$.

Jakkolwiek by oceniać politykę prezydenta Busha, zwłaszcza jej konsekwencje dla relacji z Europą, to podjęta w drugiej kadencji formuła dialogu, próba odzyskiwania so-

9 Zob. J. Rubin, Building a New Atlantic Alliance, ,Foreign Affairs” July/August 2008, nr 4, s. $101-102$. 
juszników i partnerów, rezygnacja z dzielenia Europy na „starą” i „nową” przyniosła pewne korzyści. Z pewnością przywrócono lepszą atmosferę w kontaktach z Europą jako całością, ale też z poszczególnymi państwami, w tym z Francją i Niemcami. Miało to pozytywny wpływ na funkcjonowanie NATO, zwłaszcza w Afganistanie, gdzie europejscy partnerzy - aczkolwiek bez entuzjazmu i nie w wymiarze oczekiwanym przez Waszyngton - to jednak przystali na pewne zwiększenie swoich kontyngentów wojskowych. Trzeba też przyznać, że wpływ na poprawę atmosfery w relacjach transatlantyckich miały zmiany przywódców w Niemczech i Francji, gdzie pozostających w chłodnych stosunkach z prezydentem Bushem kanclerza Schrödera i prezydenta Chiraca zastąpili Angela Merkel i Nicolas Sarkozy, oboje bardziej przychylni Ameryce.

$\mathrm{Z}$ drugiej strony załamanie $\mathrm{w}$ relacjach transatlantyckich było zbyt głębokie, aby udało się je całkowicie odbudować. Poza tym zgodzić się trzeba $\mathrm{z}$ opinią, że w wielu wypadkach było już za późno, a podjęte przez Waszyngton działania były albo nieskuteczne, albo pozbawione wiarygodności i moralnego tytułu, aby do końca urzędowania Busha w Białym Domu odrobić straty. Zresztą Europa przekonała się, że może wobec Ameryki wykazać się niesubordynacją i asertywnością. Tym bardziej że bilans prezydentury Busha to przede wszystkim osłabienie pozycji i rangi Ameryki w świecie, jej nadwerężony wizerunek i ogromne trudności w forsowaniu swoich racji. Państwa europejskie zyskały więc duży komfort w artykułowaniu własnych opinii, formułowania krytycznych wobec polityki amerykańskiej sądów, nawet zajmowania konfrontacyjnej wobec Waszyngtonu postawy. Można było odnieść wrażenie, że oba człony układu transatlantyckiego - amerykański i europejski stają się mniej asymetryczne.

Potwierdzeniem tego, jak bardzo osłabła amerykańska zdolność kreowania sytuacji w układzie transatlantyckim, było niepowodzenie działań prezydenta Busha podczas szczytu NATO w Bukareszcie na początku kwietnia $2008 \mathrm{r}$. Amerykanom nie udało się przeforsować planu objęcia dwóch dawnych republik radzieckich - Ukrainy i Gruzji specjalnym programem przygotowawczym do członkostwa w NATO. Działania prezydenta Busha skutecznie zablokowali - w obawie o reakcję Moskwy - kanclerz Merkel i prezydent Sarkozy. Była to polityczna i prestiżowa porażka Stanów Zjednoczonych, najsilniejszego i dotychczas zdolnego odgrywać rolę dominująca, wręcz narzucającego swą wolę członka Paktu Północnoatlantyckiego. Podobnie należało ocenić fakt, że europejscy partnerzy bez entuzjazmu reagowali na apele administracji Busha o zwiększenie ich kontyngentów wojskowych w Afganistanie, i to pomimo tego, że wszyscy zgadzali się co do znaczenia skuteczności misji NATO w rejonie Hindukuszu. Sojusz, który zwycięsko wyszedł z zimnej wojny, a następnie sprawdził się wobec wielu wyzwań lat dziewięćdziesiątych XX wieku, teraz stanął w obliczu realnej porażki w starciu z talibami i oddziałami terrorystów islamskich. A to mogło mieć ogromne konsekwencje dla trwałości układu transatlantyckiego, gdyż podważyłoby sens jego istnienia.

Osobnym wyzwaniem nie tylko dla samych Stanów Zjednoczonych, ale i dla całej wspólnoty transatlantyckiej pod koniec pierwszej dekady obecnego stulecia stała się Unia Europejska. Gospodarczy aspekt problemu stanowi temat sam dla siebie i nie jest przedmiotem niniejszych rozważań. Można zatem ograniczyć się tylko do stwierdzenia, że spory gospodarcze na linii USA-Unia Europejska, świadczące bardziej o narastającej atmosferze konkurencji i rywalizacji niż współpracy, na pewno nie poprawiały wzajemnych stosunków. Z drugiej jednak strony, zarówno UE, jak i Stany Zjednoczone 
stanowiły elementy tego samego zachodniego systemu norm i zasad gospodarki wolnorynkowej, uczestniczyły w procesie globalizacji i bez ich współdziałania trudno byłoby rozwiązać główne problemy ekonomiczne świata, zwłaszcza w dobie kryzysu, jaki w 2008 r. ogarnął świat. Świadomość tego faktu była i jest widoczna po obu stronach Atlantyku.

Pozostaje jednak do rozważenia polityczny aspekt relacji między Stanami Zjednoczonymi a tym wyjątkowym w dziejach naszego kontynentu tworem, jakim jest Unia Europejska. Mówiąc najprościej, wpływy polityczne UE wzrastały w ostatnich latach kosztem Ameryki. Zresztą zarówno brukselscy technokraci, jak i przywódcy głównych państw członkowskich Unii starali się uczynić z niej bądź to czynnik równowagi, bądź to globalnego pośrednika między Stanami Zjednoczonymi a resztą świata. Zwłaszcza tą jego częścia, która w taki czy inny sposób była z Ameryką mocno skonfliktowana. To trzy główne państwa Unii - Niemcy, Francja i Wielka Brytania prowadziły negocjacje z Iranem w sprawie jego programu nuklearnego. Choć rozmowy te okazały się mało skuteczne i nie przyniosły oczekiwanych rezultatów, to jednak tworzyły z tzw. trójki niezbędny czynnik ewentualnego zastopowania irańskiego projektu nuklearnego.

Podczas gdy Stany Zjednoczone nieudolnie próbowały opanować sytuację w Iraku, to Europa angażowała środki finansowe i kapitał polityczny, aby wciągnąć różne peryferyjne państwa i nie tylko je w swoją orbitę. „Wiele biednych regionów świata uświadomiło sobie, że chcą europejskiego, a nie amerykańskiego marzenia" - pisał z pewną dozą przesady amerykański politolog Parag Khanna" ${ }^{\text {"10 }}$. Chodziło o to, że w świecie pozimnowojennym znacznie ważniejsze w procesie zdobywania wpływów okazały się narzędzia „miękkiej siły” - w tym zwłaszcza oddziaływanie ekonomiczne, ale też kulturowe. Natomiast era Busha kojarzyła się z dominacją czynnika militarnego, przypominając raczej czasy zimnej wojny, oraz zatraceniem przez Stany Zjednoczone atrybutów owej „,soft power”, co już było całkowicie sprzeczne z amerykańską tradycją.

Na tym zyskiwała Unia Europejska. Jako struktura zintegrowana przede wszystkim gospodarczo sama sobą tworzyła pewien wzorcowy model rozwoju, ale też służyła pomocą i wsparciem. „Europa bardziej przypomina Merkurego - chodzi z wypchanym portfelem" - twierdził Khanna, nawiązując do słynnej tezy Kagana o Europie z Wenus i Ameryce z Marsa ${ }^{11}$. Rzeczywiście, rynek unijny stał się największym na świecie, europejskie technologie w coraz większym stopniu wyznaczały standardy, a kraje UE należały do największych dawców pomocy rozwojowej. „Europa ma do zaoferowania światu doświadczenia i umiejętności, jakich nasza planeta w obecnych opałach potrzebuje bardziej niż czegokolwiek innego" - dodawał Zygmunt Bauman ${ }^{12}$. Chodziło o wypracowaną przez Europejczyków, po dramatycznych doświadczeniach przeszłości, umiejętność korzystnego współżycia pokojowego, i to pomimo dzielących ich różnic i uprzedzeń.

Wszystko to procentowało w formie większych politycznych wpływów Unii. Stała się ona partnerem bardziej pożądanym, bo mniej kontrowersyjnym i aroganckim niż Ameryka. Nie miała skłonności do działania jak hegemon. Myśl tę rozwijał Kagan

\footnotetext{
10 P. Khanna, Pożegnanie z hegemonia, „Europa”. Dodatek do „Dziennika” 17 V 2008.

11 Ibidem.

12 Z. Bauman, Korzenie amerykańskiego zła, „Gazeta Wyborcza” 28-29 VI 2008.
} 
pisząc, że Europa chce roli światowego autorytetu moralnego oraz wpływów politycznych i ekonomicznych (jako antidotum na militaryzm) ${ }^{13}$. Zaczęła więc wyznaczać kolejny biegun nowego międzynarodowego układu. Zdaniem niektórych specjalistów tworzył się porządek, w którym wiodącą rolę odgrywała obok USA i Chin, także Unia Europejska. Ta nowa „Wielka Trójka” zaczęła dyktować reguły i wzorce, a innym państwom pozostawało tylko wybrać sobie partnerów w tym kształtowanym obecnie świecie. Intensywnie walczyła ona o wpływy, o to, kto kogo do siebie przyciagnie. $Z$ pewnością nie ułatwiało to wzajemnych relacji w ramach tego trójkąta. Miało to znaczenie szczególnie w odniesieniu do układu Ameryka-Unia Europejska, bo oba jego człony należały przecież do tego samego zachodniego świata wartości i zasad, a coraz wyraźniej zaczynała ich dzielić sfera interesów i celów, rywalizacja o wpływy i możliwości oddziaływania ${ }^{14}$.

Pozostaje jednak otwartą kwestią skuteczność działania politycznego Unii Europejskiej na arenie międzynarodowej. Czy UE jest wystarczająco zwartą i silną instytucjac, jeśli chodzi o bezpieczeństwo i politykę zagraniczną? Czy posiada mechanizmy i środki, które pozwalają skutecznie reagować na wypadek niebezpieczeństwa? Mówiąc kolokwialnie i posługując się formułą Henry'ego Kissingera, czy istnieje ów magiczny numer telefonu w Europie, pod który można by zadzwonić poszukując tam szybkiej i skutecznej reakcji na zagrożenie. Bo tylko to mogło stanowić o realnej sile Europy na scenie światowej, jej możliwości skutecznego rozwiązywania problemów politycznych.

Pod tym względem zgodzić się trzeba z opiniami, że Unia Europejska nadal nie była alternatywą dla amerykańskiego przywództwa. Oczywistą słabością UE był chociażby brak struktur wojskowych. Z. Brzeziński stawiał sprawę jasno: „Europa polityczna jeszcze nie powstała”. I odnosząc to na grunt stosunków z USA pisał: „Polityczny dialog Ameryki z Europą sprowadza się do dwustronnych stosunków z poszczególnymi państwami, a szczególnie z trzema czołowymi: Wielką Brytanią, Francją i Niemcami, które same nie potrafią zająć wspólnego stanowiska w sprawach dla Ameryki istot-

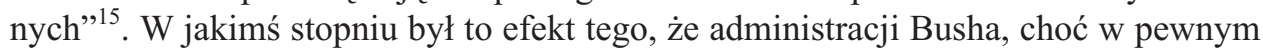
momencie odeszła od tak wyraźnego stosowania polityki dyferencjacji, jak wtedy, gdy D. Rumsfeld dzielił ją na ,starą" i ,nową”, to jednak łatwiej było rozmawiać z konkretnymi partnerami europejskim niż ze zintegrowaną całością. Ale decydował o tym przede wszystkim fakt, że Unia Europejska nadal nie była w stanie sama rozstrzygać konfliktów światowych, ani do tego nie aspirowała. Choćby dlatego, że nie posiadała realnych sił militarnych.

Ale też zbyt duże były inercja i zachowawczość tworu europejskiego. Wynikało to z różnic interesów, postaw, doświadczeń i celów, jakie niosły z sobą poszczególne państwa członkowskie. Ich odmienna ocena sytuacji i zróżnicowane oczekiwania od wielu lat uniemożliwiały wypracowanie wspólnej polityki zagranicznej oraz wspólnego stanowiska wobec mnóstwa większych i mniejszych problemów międzynarodowych. Trudno nawet było jeszcze przesądzić, czy Traktat lizboński okaże się skutecznym mechanizmem, kształtującym wspólną politykę zagraniczną.

\footnotetext{
13 R. Kagan, Koniec marzeń, powrót historii, „Europa”. Dodatek do „Dziennika” 11 VIII 2007.

14 P. Khanna, Pożegnanie z hegemoniq...

15 Z. Brzeziński, Tarcza tak, ale nie taka, „Polityka” 7 VI 2008.
} 
Tej oceny nie zmieniła nawet rola, jaką Unia Europejska odegrała podczas kryzysu gruzińskiego w sierpniu 2008 r. Jest faktem, że to prezydent Francji, sprawującej wówczas prezydencję w UE, podjął się zadania rozwiązania kryzysu. I - przy wszystkich zastrzeżeniach - temu wyzwaniu sprostał, mediując między Moskwą a Tbilisi i wypracowując dokument, podpisany przez obie strony. Jednak misji Sarkozy'ego towarzyszyła cała paleta różnych opinii i stanowisk poszczególnych państw członkowskich UE. Od skrajnie wojowniczej wobec Rosji i silnie progruzińskiej reakcji polskiego prezydenta Lecha Kaczyńskiego, który w towarzystwie przywódców republik bałtyckich Litwy, Łotwy i Estonii oraz Ukrainy, niezależnie od Sarkozy'ego wybrał się do Tbilisi, przez stanowczą wobec Moskwy postawę Brytyjczyków, po bardziej prorosyjską ocenę sytuacji, wyrażaną przez Włochy i prezydenta Czech. Co więcej, różnice występowały w samych państwach członkowskich: w Polsce między prezydentem a premierem, w Niemczech w ramach rządzącej koalicji CDU/CSU-SPD, gdzie szef dyplomacji, socjaldemokrata Frank-Walter Steinmeier był wyraźnie prorosyjski, a kanclerz Merkel bliżej było do racji Gruzji, w Czechach zaś premier nie do końca zgadzał się z prezydentem.

Ale co by nie powiedzieć o efektywności działań Unii Europejskiej, to jednak misja prezydenta Francji była na pewnym etapie rozwijania się wojny w Gruzji znaczącym i ważnym dokonaniem. Zrazu wydawało się, że nawet skutecznym, przesądzającym o zakończeniu działań zbrojnych. Natomiast administracja Busha ukazała w konflikcie gruzińskim całą swą bezradność i nieskuteczność, choć Gruzja uchodziła za jej bliskiego sojusznika (USA wyposażyły i wyćwiczyły armię gruzińską, która błyskawicznie poszła w rozsypkę w starciu z wojskami rosyjskimi). Podobnie można ocenić zachowanie NATO - głównego komponenta osi transatlantyckiej, które nie odegrało większej roli w kulminacyjnych momentach wojny gruzińskiej, podzielone co do oceny zachowań Rosji i zastosowania wobec niej sankcji. Trudno zatem było oprzeć się wrażeniu, że konflikt gruziński miał znaczenie symboliczne, gdyż dowodził swego rodzaju bezradności całego układu transatlantyckiego. Jeśli się ktoś sprawdził bardziej, to niewątpliwie zaledwie jeden jego komponent - Unia Europejska, zaś wiarygodność straciła Ameryka prezydenta Busha, osłabiając równocześnie wagę i znaczenie wspólnoty transatlantyckiej.

Wiele było czynników i wydarzeń z pierwszych lat XXI wieku, które doprowadziły do pogorszenia relacji między Stanami Zjednoczonymi a Europą i spowodowały złą kondycję osi transatlantyckiej. Składały się na nią zarówno osłabione przywództwo amerykańskie oraz większa niezależność Europy, jak i trudności w osiagnięciu porozumienia między Ameryką i jej europejskimi sojusznikami w wielu sprawach, także problemy natury militarnej związane choćby z prowadzoną operacją w Afganistanie, osłabiające wiarygodność i skuteczność NATO. Można było odnieść wrażenie, że układ transatlantycki zatracił sens bycia wspólnota, zabrakło wyraźnego spoiwa, a także tych samych celów oraz priorytetów, które wystarczająco silnie ogniskowałyby uwagę wszystkich zainteresowanych członów tego układu. Sytuację komplikował fakt, że świat coraz wyraźniej zmierzał ku wielobiegunowości, a sojusz transatlantycki nie był już niczym oczywistym. Stał się raczej odziedziczonym po poprzedniej epoce i stanowiącym element tradycji układem, a nie koniecznością.

Zatem pytanie o przyszłość relacji transatlantyckich było jednym z ważniejszych, jakie w 2009 r. stanęło przed administracją Baracka Obamy. Z nową administracją po- 
wszechnie wiązano nadzieję na poprawę stosunków Ameryki z Europą. Sam fakt, że w Europie przyjęto zmianę gospodarza w Białym Domu z ogromnymi nadziejami, wręcz entuzjastycznie - od dawna żaden amerykański przywódca nie wzbudzał takiej sympatii - stwarzał szanse na przezwyciężenie kryzysu w stosunkach transatlantyckich, tak aby wspólnota ta stała się świadomym wyborem dla wszystkich stron. Tym bardziej że wśród przywódców europejskich rosło poczucie, że złe relacje transatlantyckie osłabiają też prestiż i znaczenie Europy. Prezydent Obama już na starcie miał więc w ręku ważne atuty - sympatię, kredyt zaufania i deklarowane zainteresowanie partnerów europejskich. Istniało też dość powszechnie przekonanie, że jakiekolwiek próby odbudowy i wzmocnienia sojuszu transatlantyckiego zależeć będą w dużym stopniu od Stanów Zjednoczonych, jego najsilniejszego elementu. Jakby zapominano o odpowiedzialności i roli strony europejskiej.

Czy zatem Barackowi Obamie udało się w ciąu tych blisko dwóch lat, jakie upłynęły od objęcia przez niego urzędu prezydenckiego, przywrócić harmonię w relacjach z Europejczykami, czy zdołano wypełnić nową treścią układ transatlantycki, czy w stolicach europejskich było większe zrozumienie dla oczekiwań oraz dążeń Stanów Zjednoczonych? Czy wśród priorytetów politycznych nowej administracji Europa zajęła zgodną z jej oczekiwaniami pozycję? Wreszcie, czy Europa wykonała własną część zadania, wnosząc swój wkład w odbudowę układu transatlantyckiego? Jak zatem można zdiagnozować obecny stan relacji transatlantyckich i jakie rysują się przed nimi perspektywy?

Nie ulega wątpliwości, że kluczowe znaczenie dla odbudowy silnych więzi sojuszniczych miało przywrócenie dobrej atmosfery we wzajemnych relacjach. Służyła temu zmiana stylu uprawiania polityki w Waszyngtonie, gdzie znowu przywiązywano wagę do działań dyplomatycznych, zademonstrowano wolę współpracy i wysłuchiwania racji partnerów. Można było odnieść wrażenie, że pragmatyzm w działaniu i konsultacja zastępują dotychczasową ideologizację polityki i autorytaryzm w podejmowaniu decyzji. Europa mogła poczuć się znowu doceniana, ważna i współodpowiedzialna. Pozytywnie również odebrano w Europie zapowiedzi Obamy o zamknięciu kontrowersyjnego i sprzecznego z zasadami demokracji więzienia w Guantanamo na Kubie oraz gotowość aktywnego włączenia się do walki ze zmianami klimatycznymi w świecie. Mówiono o wycofaniu $\mathrm{w}$ niedalekiej już przyszłości amerykańskich wojsk z Iraku, większej aktywności na rzecz odbudowy Afganistanu, a wobec wrogów i przeciwników wystąpiono z ofertą rozmów i negocjacji, niemalże bez warunków wstępnych. Obserwatorzy oceniali, że Ameryka odbudowuje swoją ,soft power”, niekwestionowany atrybut jej prestiżu i znaczenia, wysoko ceniony w Europie Zachodniej. Dzięki temu wszystkiemu kondycja układu transatlantyckiego uległa pewnej poprawie.

Jednak daleko było od ideału. Pojawiły się bowiem nowe okoliczności i nowe wyzwania, które skomplikowały bieg spraw. Administracja Obamy wystąpiła z propozycjami i sugestiami, które nie spotkały się z odpowiednią, a przynajmniej oczekiwaną przez Amerykanów, reakcją strony europejskiej. Z kolei wiele państw europejskich rozczarowały niektóre gesty i działania Waszyngtonu. Nie udało się wzmocnić układu transatlantyckiego przez nadanie mu przekonującego sensu istnienia, a także uruchomienie nowego, wyrazistego impulsu. $Z$ jednej strony mieliśmy więc do czynienia z poczuciem marginalizacji Europy w globalnej polityce Waszyngtonu, z drugiej 
- utrzymującą się asertywnością i biernością Europy w odniesieniu do wielu wyzwań i problemów. Skutkiem tego było wrażenie o dalszym wzajemnym oddalaniu się Europy (Unii Europejskiej) i Stanów Zjednoczonych.

Dla Waszyngtonu czasu Obamy kontynent europejski przestał być regionem o pierwszorzędnym znaczeniu. W jakiejś mierze wynikało to ze słabnących więzi emocjonalnych między politykami amerykańskimi a przywódcami europejskimi. Choćby pochodzenie czarnoskórego prezydenta USA - ojciec z Afryki, dzieciństwo spędzone z dala od kontynentu amerykańskiego, w Azji i na Hawajach - automatycznie narzucało słabszą niż było dotąd więź emocjonalną z Europą. Zatem o bliskich związkach ze Starym Światem decydować miały teraz bardziej względy pragmatyczne niż - jak to było przez ostatnie ponad pół wieku-związki historyczne, uczuciowe lub kulturowe.

Słabnące zainteresowanie Europą wynikało też z prostego faktu, że przestała być ona przedmiotem szczególnych obaw amerykańskich o jej bezpieczeństwo, stabilizację i postępy w demokracji, jak działo się w czasach zimnej wojny i w pierwszym okresie po niej. Prezydent Obama dostrzegał Europę przede wszystkim w kontekście i w zestawieniu z innymi celów, stanowiącymi rzeczywiste wyzwanie dla amerykańskich interesów i priorytetów. Myśl tę rozwijał R. Kagan pisząc, że „Obama jest pierwszym naprawdę pozimnowojennym prezydentem USA. Nie łączy wielkich emocji z Europa. [...] Jako człowiek sterujący supermocarstwem, które ma wiele kłopotów, zastanawia się przede wszystkim nad tym, co Europa może zrobić dla niego. A jej znaczenie strategiczne maleje z roku na rok - na jej własną prośbę, z powodu tego, co Europa robi i nie robi $[\ldots]^{\prime 16}$.

Administracja Obamy oczekiwała więc, że relacje transatlantyckie nie będą tylko wspólnotą wartości i zasad, sprowadzającą się do problemu bezpieczeństwa, czyli de facto NATO, ale zyskają bardziej praktyczny charakter. Ameryka chciała Europy, na którą będzie można liczyć przy rozwiązywaniu różnych problemów i która będzie angażować się na miarę swych możliwości w różnych częściach świata, najczęściej odległych od teatru europejskiego. „Chcemy mieć silnych sojuszników. Nie chcemy być patronami Europy. Oczekujemy, że będziemy partnerami Europy" - mówił Obama podczas swej pierwszej podróży europejskiej ${ }^{17}$. Wobec różnych wyzwań, takich jak problemy globalnej gospodarki, terroryzm, groźba proliferacji broni jądrowej, konflikt bliskowschodni celem administracji Obamy była współpraca z każdym, kto okazałby skuteczną pomoc przy rozwiązaniu tych problemów. W tym Waszyngton widział szczególną rolę sojuszników europejskich.

Tymczasem państwa europejskie, choć zintegrowane w Unii Europejskiej, posiadającej już swego rodzaju ministra spraw zagranicznych, nie zdołały zaprezentować się jeszcze jako skuteczny, aktywny gracz na arenie międzynarodowej. Nie przejęły roli potęgi, którą potencjalnie Unia Europejska przecież jest. Nie chodziło tylko o to, że państwa europejskie, choć konsekwentnie krytykowały przetrzymywanie bez wyroków podejrzewanych o terroryzm w Guantanamo, to odmawiały przyjęcia uwolnionych więźniów na swoje terytorium. Ale odnieść to można było chociażby do konfliktu

16 Rozmowa z R. Kaganem pt. Obama - cudu nie było w „Gazecie Wyborczej” 16-17 I 2010.

17 Cyt. w: M. E. O'Hanlon, Obama's Solid First Year on Foreign Policy, www.brookings.ed/opinions/2010/0101_obama_foreign-_policy_ohanlon.aspx... 
bliskowschodniego, gdzie zabrakło rzeczywistej determinacji, aby zaangażować się dyplomatycznie na miarę możliwości Europy w realizację procesu pokojowego (na inaugurującym nowy etap rozmów izraelsko-palestyńskim spotkaniu w Waszyngtonie w lecie 2010 r. nie było Catherine Ashton - Wysokiego Przedstawiciela ds. Wspólnej Polityki Zagranicznej i Bezpieczeństwa UE). Europa, oczekując na działania Ameryki - w praktyce ograniczała swą rolę do pomocy finansowej dla strony palestyńskiej (około 1 mld euro rocznie). Podobnie słabo dostrzegalna była ostatnio rola Unii Europejskiej przy rozwiązywaniu groźnego i nadal nieprzezwyciężonego dylematu ambicji nuklearnych Iranu. A przecież swego czasu państwa tzw. trójki jawiły się jako ważny czynnik w rozmowach z reżimem ajatollahów.

Prestiżu Europie (Unii Europejskiej) nie przysporzyło fiasko szczytu klimatycznego w Kopenhadze pod koniec 2009 r. Wydawało się bowiem, że UE może odegrać rolę wiodącą $\mathrm{w}$ walce ze zmianami klimatycznymi, być skuteczną w negocjacjach z różnymi państwami, w tym ze Stanami Zjednoczonymi - tak zresztą w pewnym okresie było. Tymczasem konferencję klimatyczną w stolicy Danii rozegrali między sobą Amerykanie, Chińczycy, Brazylijczycy i Hindusi. Zatem rozczarowujące efekty spotkania w Kopenhadze osłabiły nie tylko autorytet Europy, ale i jej wiarę we własne siły oraz możliwości.

To, że Europa nie sprawdziła się w ostatnim czasie jako strategiczny aktor, na którego liczyły Stany Zjednoczone, wynikało też z braku gotowości państw europejskich do podejmowania większych zobowiązań i większej odpowiedzialności za bieg spraw w świecie, co wymagało często pokonania narodowego egoizmu, większego poświęcenia, zademonstrowania woli partnerskiego współdziałania z Ameryką. Warto dodać, że na polu polityki zagranicznej, a także obronnej państwa członkowskie UE zachowały silne poczucie narodowej niezależności. Trudno było zatem forsować jeden europejski punkt widzenia. Zresztą któż miałby to robić - pozbawiona charyzmy i doświadczenia baronessa Ashton? Nawet angażując się w działania NATO w Afganistanie państwa europejskie czyniły to jako indywidualni sojusznicy, silnie uzależnieni od narodowych uwarunkowań i ograniczeń.

Zresztą Afganistan stał się - w amerykańskiej ocenie - doskonałym potwierdzeniem braku woli zdecydowanego angażowania się Europy i wspierania wysiłków amerykańskich. Pod koniec marca 2009 r. prezydent Obama przedstawił nową strategię dla Afganistanu, której celem było odwrócenie losów wojny pod Hindukuszem. Miała ona bardziej polityczny niż militarny charakter: proponowano podjęcie negocjacji z różnymi siłami w Afganistanie, w tym z umiarkowanymi grupami talibów, rozszerzenie programu szkolenia afgańskich żołnierzy i policjantów, podjęcie wysiłku na rzecz odbudowy i rozwoju Afganistanu. Trzeba przyznać, że plany te, zwłaszcza dotyczące zwiększonych środków cywilnych i politycznych, spotkały się z życzliwą reakcją sojuszników europejskich. Ale gdy Obama zaproponował sojusznikom europejskim skierowanie pod Hindukusz dodatkowych żołnierzy, odzew nie był już tak przychylny. Europa - pomimo niekwestionowanej sympatii dla nowego gospodarza w Białym Domu - okazała się już partnerem trudniejszym i na pewno nie tak spolegliwym jak kiedyś. Tylko z największym trudem udało się zebrać 4-tysięczny kontyngent, składający się zresztą głównie z policjantów i szkoleniowców. Jednak pomimo tego brak było w Afganistanie jakichkolwiek sukcesów w walce z talibami i al Kaidą, co prestiżu Ameryce, Europie i wspólnocie transatlantyckiej nie przysporzyło. 
Jeszcze słabszy był odzew sojuszników europejskich na kolejną strategię afgańską, ogłoszoną przez Obamę 1 grudnia 2009 r. Nowy plan wobec Afganistanu zakładał wysłanie następnych 35 tys. żołnierzy amerykańskich pod Hindukusz oraz przewidywał zwiększenie kontyngentów innych państw, głównie z NATO. Obama dowodził, że świat musi czuć się odpowiedzialny za tę wojnę. Był to więc kolejny test na solidarność, zwłaszcza atlantycka. Jednak Europa - już tradycyjnie - bez entuzjazmu zareagowała na ten pomysł. Wielka Brytania, najbardziej lojalny sojusznik Stanów Zjednoczonych, zaoferowała ledwie 500 żołnierzy, podobnie Turcja. W Niemczech kwestia wysłania kolejnych żołnierzy wywołała debatę publiczna, w której przeważały głosy sprzeciwu. Dopiero pod koniec stycznia 2010 r. Merkel ogłosiła decyzję o wysłaniu kolejnych żołnierzy. Przynajmniej na tym etapie Europa z największym trudem zdawała egzamin na solidarność atlantycką.

Co więcej, zabrakło wspólnego namysłu nad strategią w Afganistanie. Europejscy politycy deklarowali wprawdzie, że powodzenie misji afgańskiej jest czynnikiem ich narodowego bezpieczeństwa, ale w praktyce traktowano jąjako niemalże wyłączną odpowiedzialność Stanów Zjednoczonych. Oznaczało to również minimalny wpływ Europy na określenie strategii działań w Afganistanie, na to, jak prowadzona jest wojna, tutaj w zasadzie Europa łatwo i chętnie poddała się przywództwu Ameryki. Nasiliło się więc wzajemne transatlantyckie rozczarowanie, a Europa nie sprawdziła się jako zaangażowany i odpowiedzialny partner, którego Waszyngton wyraźnie potrzebował. Partnera dysponującego wspólnym, jednoznacznym stanowiskiem.

Nie wypracowano więc jeszcze owego wspólnego dla Europy numeru telefonu, o którym swego czasu mówił H. Kissinger, i pod który Waszyngton mógłby zadzwonić oczekując solidarnego działania Europy. Ameryka Obamy liczyła na powstanie bardziej zjednoczonej i skutecznej Europy, ale się rozczarowała. Dlatego między innymi prezydent Obama odmówił udziału w szczycie Stany Zjednoczone-Unia Europejska, planowanym na maj 2010 r. Uznał - po rozczarowującym spotkaniu w Pradze na początku kwietnia 2009 r. - że będzie to znowu wysłuchanie, czasami rozbieżnych i wykluczających się opinii oraz poglądów 27 przywódców państw członkowskich UE, z czego nic konkretnego dla przezwyciężenia globalnych wyzwań nie wyniknie. A on liczył na przedstawienie wspólnego i przez to znaczącego stanowiska całej Europy wobec najważniejszych problemów współczesnego świata.

Kolejne pytanie dotyczy tego, czy udało się wypełnić głębszą treścią relacje transatlantyckie. Nie ma wątpliwości, że służyć temu miało zdynamizowanie Paktu Północnoatlantyckiego, znajdującego się po erze Busha w nie najlepszej kondycji. Wprawdzie w okresie prezydentury Busha przyjęto do Sojuszu nowych członków, w tym trzy byłe republiki radzieckie. Tym samym NATO przekroczyło to, co jeszcze kilkanaście lat wcześniej wydawało się niemożliwe - granice dawnego Związku Radzieckiego. Z kolei członkostwo Słowenii oznaczało, że w Sojuszu znalazła się pierwsza z byłych republik Jugosławii, gdzie jeszcze niedawno toczyła się najbardziej krwawa od zakończenia II wojny światowej wojna w Europie. W ten sposób dokonał się kolejny akt w procesie przezwyciężania podziałów w Europie i jednoczenia się kontynentu.

Ale to co dla jednych było poszerzaniem strefy stabilizacji i bezpieczeństwa, dla innych oznaczało tworzenie z NATO mniej sprawnej i skutecznej instytucji, w której decyzje zapadały powoli i z trudnością, drogą wyczerpujących negocjacji i konsultacji. 
O słabszej kondycji organizacji, uchodzącej dotychczas za najbardziej skuteczną, stanowiąca fundament bezpieczeństwa jej członków, świadczyły niepowodzenia misji w Afganistanie. A zatem od Stanów Zjednoczonych, najsilniejszego państwa członkowskiego Sojuszu oczekiwano - obok przełamania impasu w Afganistanie - wypełnienia nową treścią wspólnoty atlantyckiej, nadania impulsu do opracowania nowej koncepcji strategicznej NATO. Konieczne było przede wszystkim zredefiniowanie na nowo roli Sojuszu, określenie charakteru wewnętrznych relacji, wytyczenie celów, zasięgu, metod i kierunku działania. Był to problem tym bardziej palący, że poprzednia koncepcja strategiczna przyjęta została w 1999 r. Od tego momentu wydarzyło się tak wiele, zaszły zasadnicze zmiany na arenie międzynarodowej, z nową siłą ujawniły się różne zagrożenia.

Tymczasem przez pierwszy rok urzędowania Obamy uczyniono niewiele, aby te oczekiwania spełnić. Dlatego zdaniem niektórych analityków nie udało się skrystalizować koncepcji, czym ma być NATO. Nie znaleziono odpowiedzi, w jakim stopniu celem Sojuszu powinny być misje ,out of area” lub w jakim kierunku powinno iść jego rozszerzenie. Innymi słowy Pakt Północnoatlantycki pozostał - jak to zgrabnie ujął Aleksander Smolar - „duchem w poszukiwaniu wcielenia”. Koncentrując się na zadaniach bieżących, związanych głównie z misją w Afganistanie, pozostawiono na boku działania strategiczne, związane z przyszłością Sojuszu, jego zdynamizowaniem i umocnieniem skuteczności, określeniem charakteru i zadań. Dopiero pod koniec 2010 r. miano finalizować kwestię nowej koncepcji strategicznej Sojuszu (wypracowanej w połowie 2010 r. przez specjalną grupę ekspertów). Trudno zatem dzisiaj o jej ocenę. Jednak zwlekanie z przygotowaniem, a następnie przyjęciem nowej koncepcji z pewnością nie służyło poprawie nie tylko kondycji samego Sojuszu, ale również umocnieniu więzi transatlantyckich.

Należy natomiast zastanowić się, czy Rosja i kwestia stosunków z nią wywarła wpływ na układ transatlantycki. Wszak czynnik, kiedyś radziecki, obecnie rosyjski stanowił i stanowi jeden z najważniejszych punktów odniesienia zarówno dla Europy, jak i Stanów Zjednoczonych. Jeśli należałoby wskazać pole, na którym administracja Obamy odcisnęła pewne, głównie spektakularne piętno, to były to relacje z Rosją. Już w lutym 2009 r. zapowiedziano nowe otwarcie w relacjach z Moskwą. „Czas nacisnać klawisz reset i zrewidować wiele obszarów, w którym możemy i powinniśmy współpracować" - oznajmił wiceprezydent Joseph R. Biden ${ }^{18}$. W dzisiejszym świecie prostych konstrukcji słownych określenie reset stało się niemalże hasłem, którego realizacji administracja Obamy poświęciła wiele czasu i wysiłku. Na pewno kwestia poprawy atmosfery w stosunkach Waszyngton-Moskwa żywo interesowała także europejskich partnerów Ameryki. Udział Rosji w rozwiązywaniu, ale też komplikowaniu niektórych problemów, a nawet podgrzewaniu atmosfery był bowiem bezdyskusyjny. Wiadomo było, że Rosja może być pomocna w Afganistanie, w kwestii irańskiego programu nuklearnego, nieodzowna jako partner w rozmowach rozbrojeniowych START, a nawet przy rozwiązywaniu konfliktu bliskowschodniego i w kwestiach polityki energetycznej. Trudno też zaprzeczyć, że budowa trwałego bezpieczeństwa w naszym

18 J. R. Biden, Speech at the 45th Munich Conference, 7 II 2009, www.securityconference.de/konferenzen/rede.php?menu_2009=\&menu_konfer. 
regionie, a także podołanie wyzwaniom globalnym bez współpracy z rosyjskim partnerem, będzie niemożliwe, a przynajmniej znacznie trudniejsze.

Jednak ocena „resetowania” stosunków z Moskwą nie była w Europie jednoznaczna. Zdaniem niektórych analityków strona amerykańska okazała się zbyt miękka dla Moskwy. Tak bowiem wielu komentatorów oceniło fakt rezygnacji przez Waszyngton we wrześniu 2009 r. z projektu tarczy antyrakietowej, której elementy miały być instalowane w Polsce i Czechach. Jakkolwiek trudno zaprzeczyć argumentom natury militarnej i finansowej, które wpłynęły na decyzję administracji Obamy, to jednak nie można było zapomnieć o politycznym aspekcie całej sprawy - uwzględnieniu interesów Rosji, która nie zgadzała się na rozmieszczenie w krajach jej dawnej strefy wpływów elementów instalacji amerykańskiej. Gdy więc w myśleniu Obamy i jego współpracowników Rosja stała się państwem nieodzownym, jeśli idzie o przezwyciężanie wyzwań na arenie międzynarodowej, zdecydowano się na przyjazny wobec niej gest.

Wywołało to ostrą reakcję. Najsilniej brzmiały głosy z Europy Środkowo-Wschodniej. Można powiedzieć bez większej przesady, że nadwerężenie zaufania do Waszyngtonu w państwach tej części Europy to jeden $\mathrm{z}$ najbardziej jaskrawych przykładów ujemnego bilansu administracji Obamy w relacjach ze Starym Światem. Wszak ten region Europy, leżący na strategicznej granicy z Rosją pragnął silnych więzów z Ameryką i był gotowy do pełnej lojalności oraz spolegliwości wobec amerykańskiego supermocarstwa. Docenienia tego faktu w Waszyngtonie od 2009 r. nie było. Bez odzewu pozostał list autorstwa zatroskanych o stan relacji z Ameryką znanych postaci i autorytetów z Europy Środkowo-Wschodniej, w tym Lecha Wałęsy i Vaclava Havla, skierowany do administracji Obamy w lipcu 2009 r. Potem przyszła rezygnacja z tarczy antyrakietowej. Negatywnego rezonansu tej decyzji nie były w stanie już zmienić ani plany zrealizowania innej technologii antyrakietowej, ani kurtuazyjna podróż wiceprezydenta Bidena do stolic państw środkowoeuropejskich. Europa Środkowo-Wschodnia nie stała się żadnym znaczącym partnerem (nawet asymetrycznym) dla Stanów Zjednoczonych. A przecież chodziło nie tylko o danie satysfakcji państwom Środkowo-Wschodniej Europy, ale mógł to być czynnik służący relacjom transatlantyckim, a przynajmniej umocnieniu więzi tej części Europy ze Stanami Zjednoczonymi.

Generalizując problem, trudno nie odnieść wrażenia, że polityka administracji Obamy wobec Rosji wpędziła Europę w stan niepewności, tworząc nowe podziały, a przede wszystkim komplikując relacje transatlantyckie. $Z$ drugiej strony należy podkreślić, że sytuacji nie ułatwiało zróżnicowanie postaw państw europejskich wobec rosyjskiego giganta. Rację mieli również ci analitycy, którzy zarzucali Europie brak głębszej refleksji nad relacjami z Rosja. W Unii Europejskiej nie było dyskusji ani o nowej strategii bezpieczeństwa zaproponowanej przez rosyjskiego prezydenta Dmitrija Miedwiediewa, ani o bezpieczeństwie energetycznym. W tej sytuacji można podejrzewać, że cokolwiek Stany Zjednoczone nie uczyniłyby wobec Rosji, spotkałoby się to z krytyka, płynącą z tych lub innych stolic europejskich, wywołując niepotrzebne napięcia i spory we wspólnocie transatlantyckiej oraz prowadząc do jej osłabienia.

Jakie wobec tego perspektywy rysują się przed relacjami euroatlantyckimi? Jakie działania należałoby podjać i jakiej zmianie powinno ulec wzajemne nastawienie Ame- 
ryki i Europy, aby układ transatlantycki odzyskał sens istnienia i swoje znaczenie? Przede wszystkim należy uznać, że Europa - choć z różnych, nawet niezależnych od niej względów - nie będzie traktowana przez Stany Zjednoczone priorytetowo, a przynajmniej nie w takiej formule, jak było w okresie zimnej wojny, a nawet w latach dziewięćdziesiątych, gdy to Ameryka zainteresowana była postępami demokracji we wschodniej, pokomunistycznej części kontynentu. Powtórzmy to jeszcze raz, dzieje się tak dlatego, że Stary Świat przestał być obiektem poważnej obawy Stanów Zjednoczonych o jego bezpieczeństwo i rozwój. Trzeba jednak mieć nadzieję, że Europa (Unia Europejska) będzie nadal czołowym partnerem Waszyngtonu na różnych polach, i przez to pozostającym w kręgu jego szczególnego zainteresowania.

Aby tak się stało, Europa musi zaprezentować się jako gotowy do działania, aktywny aktor na scenie międzynarodowej. Do tego potrzebna jest wola wzięcia większej odpowiedzialności za bieg spraw w świecie, zaangażowania się w rozwiązywanie problemów globalnych i to w różnym wymiarze, także militarnym. Konieczne jest również wypracowanie przez Europę jednolitej polityki zagranicznej, wspólnego stanowiska wobec kluczowych wyzwań, a przynajmniej działanie w tym kierunku. Zewnętrzna aktywność UE musi wyjść poza kwestie gospodarcze, poza handel i konkurencję, gdzie zresztą mamy do czynienia z dość jednoznacznym stanowiskiem. Brak jednak tego wspólnego punktu widzenia na wiele innych „zagranicznych” kwestii. Tymczasem jeżeli państwa członkowskie UE chcą coś znaczyć w świecie i być dobrze postrzeganymi przez Waszyngton, muszą mówić i działać razem, czasami nawet wywierając skuteczny nacisk. Traktat lizboński być może będzie służył tej sprawie, zapewniając mocniejsze przywództwo w Unii Europejskiej i dostarczając narzędzi instytucjonalnych, choćby poprzez zbudowanie unijnej służby dyplomatycznej. W efekcie łatwiej będzie uzgodnić wspólne stanowisko, a następnie solidarnie i skutecznie je reprezentować.

$\mathrm{Z}$ pewnością nie będzie to proces łatwy, biorąc pod uwagę naturalną i zrozumiałą skłonność państw Unii Europejskiej do zabiegania o własne interesy i przedstawiania narodowych punktów widzenia. Nawet Europejska Służba Działań Zewnętrznych nie będzie w stanie zdefiniować wspólnej polityki zagranicznej. Ta zależna będzie od woli politycznej rządów poszczególnych państw. Dlatego kraje europejskie powinny najpierw określić wspólne cele i stanowiska w polityce zagranicznej tam, gdzie różnice interesów narodowych są najmniejsze. Dotyczy to części Azji, Afryki oraz Ameryki Południowej. Choć wiadomo, że np. w stosunku do Chin nie da się uniknąć podziałów i różnic, wynikających z jednej strony ze stosunku do kwestii praw człowieka, z drugiej - różnej wagi związków gospodarczych.

Trzeba również podjąć dyskusję, która pozwoli określić tematy kluczowe i najważniejsze z punktu widzenia stosunków transatlantyckich. Wypracować wobec nich wspólne stanowisko Europy, które będzie można przedstawić Stanom Zjednoczonym. Wzmocni to znaczenie i rangę europejskiego partnera w oczach Amerykanów. Już dzisiaj można wskazać kilka takich obszarów, gdzie wspólne stanowisko Europy (Unii Europejskiej) oraz gotowość wprowadzenia go w życie lub przynajmniej przedyskutowanie z USA potwierdzi rosnącą pozycję i znaczenie europejskiego partnera. I tak, może należałoby się zastanowić nad opracowaniem europejskiej strategii dla Afganistanu. Oznaczałoby to z pewnością większe zaangażowanie państw europejskich lub 
nawet zmianę taktyki, ale mogłoby równocześnie prowadzić do wzrostu roli Europy w relacjach transatlantyckich.

Takim ważnym dla układu transatlantyckiego tematem pozostaje Rosja. Trzeba zastanowić się, czy Europa nie powinna wziąć na siebie większej odpowiedzialności za relacje z państwem rosyjskim. To będzie oznaczało między innymi włożenie większego wysiłku w urzeczywistnienie Partnerstwa Wschodniego, aby przestało być tylko „powabnym” hasłem, a stało się zespołem realizowanych, wprowadzanych wspólnym wysiłkiem w życie konkretnych inicjatyw. Rosja powinna stać się także przedmiotem wieloaspektowej dyskusji, podejmowanej na różnych forach unijnych. Europa, skutecznie radząca sobie z Rosją, mająca jasno skrystalizowany jej ogląd i wyraźnie sformułowane pod jej adresem oczekiwania będzie z pewnością lepiej odbierana w Waszyngtonie niż Europa, wyglądająca amerykańskich inicjatyw i działań, a później różnie, niekiedy ostro je oceniająca. Nie można także dopuścić do sytuacji, gdy o względy Moskwy będą ze sobą konkurowały Europa i Stany Zjednoczone. Wówczas bowiem Rosja będzie podnosiła stawkę i wygrywała swoje kosztem między innymi osłabiania więzi transatlantyckich.

Bliski Wschód, a zwłaszcza kwestia izraelsko-palestyńska oraz zagrożenie związane z irańskim programem nuklearnym, musi stać się przedmiotem większej troski Unii Europejskiej, i to nie tylko w aspekcie gospodarczym, ale także politycznym. Może należałoby połączyć te dwa elementy i spróbować wykorzystać potencjał ekonomiczny UE do zwiększenia nacisku, czy to na Iran, aby porzucił swoje ambicje nuklearne czy na strony sporu izraelsko-palestyńskiego, aby stworzyły warunki dla powodzenia procesu pokojowego. Byłyby to działania jednoznacznie wspierające wysiłki administracji Obamy, która bez większych sukcesów próbuje rozwiązać te główne problemy bliskowschodnie.

W tych i wielu innych obszarach - od zmian klimatycznych, poprzez regulacje finansowo-gospodarcze, problemy bezpieczeństwa globalnego i regionalnego, wreszcie zagrożenia terrorystycznego, które nie powinno zniknąc z pola widzenia wspólnoty transatlantyckiej - Europa ma wiele do zrobienia. Nie chodzi tylko o to, aby strona europejska przedstawiała swoje argumenty, oceny i sugestie, ale by była gotowa do dyskutowania nad nimi z partnerem amerykańskim, nawet ostrego spierania się z nim, a następnie aktywnego uczestniczenia w ich realizacji.

Aby jednak wypracować prawdziwe partnerstwo transatlantyckie, czyli skuteczne i znaczące na arenie międzynarodowej, konieczne jest też uruchomienie inicjatywy ze strony Ameryki. Oczekiwanie, że Europa będzie bardziej aktywna i odpowiedzialna na arenie międzynarodowej, to zaledwie jeden z głównych warunków. Także Stany Zjednoczone muszą konsekwentnie trzymać się zasady, że bliskie, silne i partnerskie relacje z Europą (Unią Europejską) leżą w ich interesie (bardziej niż rozważane coraz częściej przez analityków strategiczne partnerstwo USA z Chinami). Wzmacniają bowiem amerykańskie możliwości działania w świecie, podnoszą rangę i skuteczność Ameryki. Jeśli Stany Zjednoczone chcą realizować w polityce globalne cele, muszą posiadać strategicznych sojuszników. Takim naturalnym sojusznikiem - zwłaszcza w świecie zmierzającym ku wielobiegunowości - jest i powinna pozostać Europa, tym bardziej że jest to wspólnota tych samych zasad, wartości i standardów. Musi być ona jednak traktowana jako partner, z którym ustala się cele, metody, określa zagrożenia i wyzwania, a następnie wspólnie działa. 
Pokusa ignorowania lub marginalizowania kontynentu europejskiego - jakoś już w polityce amerykańskiej zauważalna - powinna być zdecydowanie odrzucona. Podobnie jak naturalna skłonność Waszyngtonu dzielenia Europy w konkretnych sprawach i wobec różnych problemów. Przeciwdziałaniem tym tendencjom będzie jedność Europy, jej umiejętność wypracowania i prezentowania wspólnego stanowiska. Nie unikniemy wprawdzie uprawiania stosunków bilateralnych, wszak różne państwa europejskie szczycą się swoimi „wyjątkowymi”, „specjalnymi” lub „szczególnymi” relacjami z amerykańskim supermocarstwem, nie powinny one jednak w optyce Waszyngtonu przesłaniać wagi znaczenia układu transatlantyckiego jako całości lub znaczenia Unii Europejskiej jako ważnego gracza na arenie międzynarodowej. Odnosi się to zresztą i do państw europejskich, które nie powinny przekładać swoich stosunków z Waszyngtonem nad lojalnością wobec Unii Europejskiej.

Choć Ameryka i Europa tworzą wspólnotę wartości, zasad i standardów, to trudno wykluczyć w najbliższej przyszłości coraz wyraźniejsze różnicowanie się interesów amerykańskich i europejskich (Unii Europejskiej), zwłaszcza w sferze gospodarczej, ale nie tylko. Stany Zjednoczone muszą przystać na sytuację, w której Unia Europejska będzie wykłócała się o własne interesy i własny punkt widzenia. Ważne, aby strona amerykańska zdolna była uznać i zaakceptować wiarygodne argumenty i motywacje Europejczyków. Podobnie jak Ameryka nie będzie składać na ołtarzu sentymentów i nostalgii własnych interesów narodowych, tak też sama powinna uznać racje i priorytety partnerów europejskich, a następnie dążyć do osiągnięcia kompromisu. Bardziej kłótliwe relacje transatlantyckie wcale nie muszą być słabsze i mniej funkcjonalne. Problem polega tylko na woli szukania rozwiązań i przezwyciężania trudności w imię osiagania wspólnych celów.

Jakkolwiek relacje transatlantyckie powinny mieć prawdziwie partnerski charakter, to jednak liczyć się będzie również determinacja i zdolności przywódcze Stanów Zjednoczonych. Polityka czystej dyplomacji, ukazywanie przede wszystkim łagodniejszej twarzy Ameryki - co było cechą charakterystyczną działań administracji Obamy - nie zawsze wzmacniało rangę USA w świecie, niekoniecznie wpływało dobrze na skuteczność i wartość układu transatlantyckiego. Nie negując znaczenia zmiany wizerunku Stanów Zjednoczonych w świecie - co było niezbędne jako punkt wyjścia po erze Busha - trzeba jednak podkreślić, że od Ameryki, która wprawdzie zatraciła już rangę hegemona, ale utrzymała atrybuty supermocarstwa, wymagać należy większej skuteczności, determinacji i odwagi w działaniu.

Oczekiwać też trzeba wyraźnego zdynamizowania NATO - filara wspólnoty transatlantyckiej, przywrócenia mu spójności i skuteczności, a przez to znaczenia i rangi. Rola Stanów Zjednoczonych - najsilniejszego państwa członkowskiego Sojuszu - jest tutaj niekwestionowana. Przetrwanie NATO w dobrej kondycji i jego skuteczne funkcjonowanie zależy więc w dużej mierze od tego, jak bardzo Amerykanie będą zainteresowani usprawnieniem, zdynamizowaniem i umocnieniem tego Sojuszu. Jak bardzo w ten proces się zaangażują. Ważnym czynnikiem będzie niewątpliwie nowa strategia NATO, której przyjęcie spodziewane jest w listopadzie 2010 r. Od niej w dużej mierze zależeć będzie przyszłość Paktu Północnoatlantyckiego.

A zatem przed Ameryką i Europą (UE) stoją ważne i trudne zadania. W wielobiegunowym, dość chaotycznym, pełnym wyzwań i problemów świecie partnerstwo 
transatlantyckie jest potrzebne zarówno Stanom Zjednoczonym, jak i państwom europejskim. Jednak utrzymanie tej wspólnoty będzie wymagało od Europy więcej aktywności i odpowiedzialności, zaś od Ameryki dalszego zaangażowania i uznania dla rangi Europy (UE). Nic tak nie wzmocni stosunków transatlantyckich, jak lepsi i silniejsi partnerzy po obu stronach tego układu, przekonani o słuszności jego utrzymania. 